\title{
WEIGHTLESSNESS AS A PREREQUISITE FOR THE IMPLEMENTATION OF BIOLOGICAL LIFE SUPPORT SYSTEM
}

\author{
G. I. MELESHKO, Ye. Ya. SHEPELEV \\ Institute for Biomedical Problems, Moscow, Russia
}

Received June 5, 1995

Accepted June 6, 1996

\begin{abstract}
Meleshko, G. I., Ye. Ya. Shepelev: Weightlessness as a Prerequisite for the Implementation of Biological Life Support System. Acta vet. Brno 1996, 65: 43-50.

The implementation of human Biological Life Support System (BLSS) in the conditions of weightlessness requires a broader, ecological approach to the analysis of manifestations of weightlessness in living systems as compared to the traditional morphophysiological approach common for gravitational biology. For a stable functioning of BLSS, as an ecological system the most decisive are superorganism levels of biological organization from population to ecosystem. On these levels, the weightlessness effects may manifest themselves even if no primary biological effects on the organism level are noted.

In this paper, possible weightlessness effects on living systems are discussed as well as the consequences of these effects. On different levels of organization of the living matter, from a cell to an ecosystem, weightlessness can exert different effects and these may come to the fore by different mechanisms.
\end{abstract}

Ontogeny, ecology, unicellular organisms, quail, gravitational biology, population, biocenosis

Modern gravitational biology directed mostly at the study of separate organisms and their subordinate levels (cellular and subcellular) gives no answer to the question of possible existence under the conditions of weightlessness of whole ecological systems where the levels above that of organism are decisive, i. e. the population, biocenotic, and ecosystem levels. This inspired us to consider again, if only theoretically, the general problem of biological or other significance of weightlessness, of its possible influence mechanisms and points of impingement on different hierarchic levels of living systems.

At the present stage it is important to state that the notion of the biological significance of weightlessness is essentially ambiguous. At various levels of biological organization, from the single organism to the ecosystem, weightlessness can make itself felt in different ways, and its effects can be carried out by qualitatively different mechanisms. The ideas generated by this analysis are schematically presented in Fig. 1. The first way - a direct, primary influence of weightlessness on elementary biological processes, such as metabolism, development, growth, proliferation at the cell and unicellular organisms levels - has not received a convincing confirmation, in spite of many-years efforts in this field. The conclusion about the absence of any specific effect of weightlessness on these main manifestations of life becomes more and more obvious. The very possibility of such an effect has no theoretical grounds yet ( $\mathrm{Parf}$ y o n ov 1988).

The second way of influence is not immediate, but performed through the change of gravitationally dependent physiological functions of an organism where they can manifest themselves. Here we mean the change of such functions as gravireception and the spatial orientation, haemodynamics, motor function and the connected with it processes of water-salt exchange of the body. The majority of information in this field have been received by vast research of long-duration space flights of man which have shown not only the facts of weightlessness influence, but also the mechanisms of their origin, carried out through the gravitationally dependent physiological functions. Thus, the widely known facts of weightlessness influence on the level of an adult organism do not present its primary effects, but 


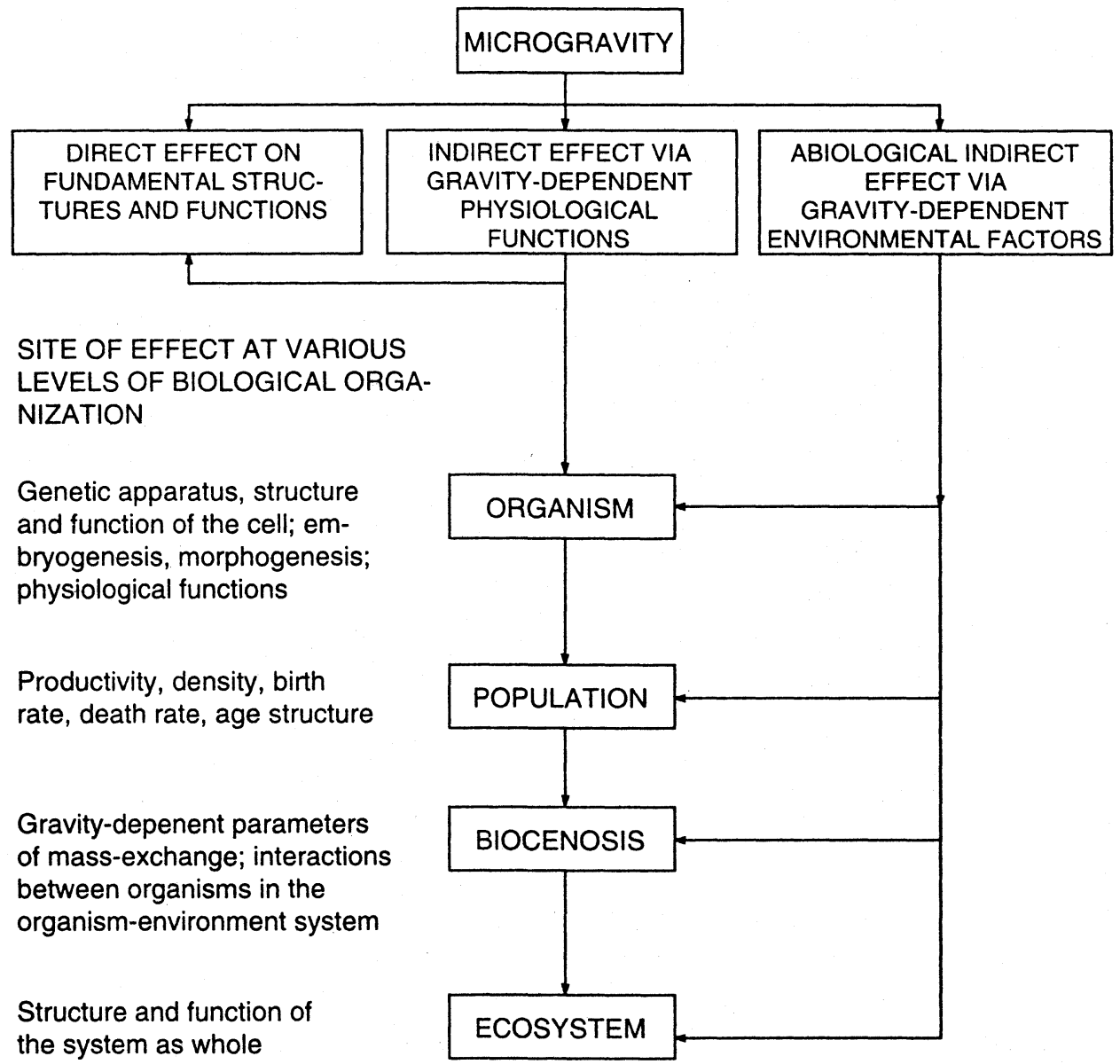

have a secondary origin. The third way of weightlessness influence is not immediate either. It takes place through the change of gravitationally dependent factors of the environment. Here we mean the impairment of the gravitationally dependent distribution of gas, liquid and solid environment phases, determine the organism's position within the inhabited phase, its motor behaviour, distribution of trophic resources in the environment, mass transforming processes. In this case absence of sedimentation and of heat convection acquires a great ecological significance. This way of weightlessness influence is especially important on the population level, where the organisms exist in more or less dense populations in which there exist the intrapopulation gradients of environment and food resources and the necessity of competition for possessing these resources. In ecosystems of a considerable scope, this way is simply inevitable while the initial condition of the very beginning and evolution of life on Earth was a gravitationally organized biosphere structure with a strict delimitation of its principal habitation environments - atmosphere, hydrosphere and upper layers of Earth.

The above scheme allows to discuss yet another aspect of the weightlessness influence problem, which concerns the substratum itself, the application points of weightlessness activity on different levels of live creatures organization. Each of these levels possesses the 
inherent status criteria. They transform internally the significant changes which have sprung up at the previous levels into status criteria of the given level with the inherent to it application points and mechanisms of manifestation of weightlessness effects.

It is well-known that the life on Earth has a discrete character and its elementary manifestation, its separate „quanta" is each individual, each organism with its sublevels and subsystems, which depend on the complexity of its structure. It is a single organism which presents the direct receiver, the detector of environment factor effects, including weightlessness. This primary, lower level of life organization includes all the stages of an individual's ontogenetic development, from a fertilized ovum to an adult organism with the sources for the next generation. All this complies an ontogenetic level, the first level of weightlessness application which is inexactly named an "organism" one. Of course there may arouse objections as to the possibility of singling out and studying suborganism and subcellular structures and organs. But the point here is the forms of independent existence of life which is manifested in every individual as its bearer and continuer. An organism can be dissected and studied up to minute fragments, but the latter are not autonomous bearers, and especially continuers of life, and therefore they are not considered in application to ecological systems.

The application points of the weightlessness effect on the ontogenetic level theoretically may be any elementary life manifestations usually mentioned in its definition, as well as various physiological functions: nutrition and metabolism, growth, development, reproduction. The final ecological result of the changes arousing on this level may be the change (most probably reduction) of a relative viability of the individuals - of the individual's life duration and reproduction capacity.

Single individuals are known to be able to exist only in artificial conditions. In nature they coexist with their like within the populations, biocenoses etc. Hence the effects of weightlessness which manifest themselves on the ontogenetic level, can lead to changes on other, higher organizational levels, too. But this is not necessary, because the changes on an individual level may be smoothed down due to physiological, morphogenetic and genetic regulation, or else due to the mechanisms of population and biocenotic regulations under protection of which any ecosystem exists.

The effects of weightlessness on the population level integrate its influence in the changes of the main criteria of the population status (density, productivity, generation structure, birth rate, death, rate) which reflect not only the current status of the population but also its nearest prospects.

The effects of weightlessness on the levels of biocenoses and ecosystems are more numerous and diverse, and the answers are more complicated and less predictable, because on these levels the interrelation of many population takes place, and the environment as an independent object of weightlessness influence, presents usually all its phases - the solid, liquid and gaseous ones. The system status criteria on these levels acquire a more and more generalized character and finally are reduced to the impairments of the stability of the ecosystem's structure and function as a whole.

Thus the superorganism levels of living systems are not only the objects of weightlessness effects, but also the instrument for estimating ecological importance (or unimportance) of the changes on the ontogenetic level. This shows the necessity of a new stage in the development of gravitational biology, at which the object of study must be the living organisms on various levels of biological organization. In this case the study of separate changes on the ontogenetic level may be expanded to research of their long-duration fate in populations, biocenoses and integral ecosystems.

The main conclusion of the analysis of the gravitation role if the fact that any success in creating and studying ground-based models of BLSS as closed ecosystems will have no clear 
future without studying their main functional characteristics in the conditions of weightlessness. This made us pass from the theoretical analysis of the issue to the possible experimental study, in spite of the growing difficulties in the methodical and equipment provisions for the flight experiments on space objects.

In this connection we have even earlier come across a possibility of the wrong interpretation of the observed effect of weightlessness in the course of studying the unicellular algae populations. In the very first experiment with a Chlorella heterotroph culture the increase of the cells number during the experiment amounted to $50 \%$, and in the second, a more prolonged experiment it increased almost by 2.5 times as compared with control (Kordium et al. 1976; Poliv od a 1988). Similar results were received while studying the growth of algae and bacteria by other scientists. In the course of the following analysis it became clear that the algae suspension in the conditions of weightlessness had distributed along all the walls of a rectangular vessel, while in the ground-based control it had been situated, naturally, on one of them, that is on the bottom. As a result, the surface of the suspension contact with the air in flight was by several times larger than in the control. This had considerably increased the gas exchange conditions of the flight culture and so it seems a quite sufficient reason of the culture growth acceleration as compared to the control, whose growth conditions appeared to be inadequate.

In the following experiments of this series, in the ground-based control those vessels were used, whose bottom area was equal to the sum of internal surfaces of the flight equipment, and in this case the growth rate of the experimental culture did not differ from that in the ground-based control (M e le s h k o et al. 1979). In these experiments the Chlorella culture served as an object, which contained up to $10^{-8}-10^{-9}$ cells per $1 \mathrm{ml}$ by the end of the experiments. At such a rate of actively growing culture it can be considered as a closed population. The population characteristics of the algae suffered no changes in the flight conditions. The number of dead cells and the cell of lowered vitality remained within the limits of natural variations; the correlation of different generation groups within the population did not change either. The age structure of the Chlorella culture in all the experiments was inherent to quickly growing populations where young individuals prevailed. This was characteristic of both the 2-3rd generations of individuals in shorter experiments, and the 5th generation in the 15-day experiment (Melesh ko et al. 1986, 1991, 1992; S y tch ov 1983).

Later on these results were confirmed with an actively growing autotroph Chlorella culture which was included into a microecosystem where the algae provided for the gas exchange of heterotroph components (fish and microorganisms), as well as for trophic requirements of the attending microflora in the dissolved organic matter Meleshko et al. 1992. Within the ecosystem the algae also kept their physiological and population characteristics, and maintained the existence of the community throughout the experiments.

Thus the analysis of physical conditions of the environment in the experiments and its introduction of physically adequate control allowed to state that a considerable increase of the algae growth rate which had been observed in the first experiment, was conditioned not by its direct influence upon the mechanisms of growth, development and proliferation of the cells, but indirectly, through the change of the environment's physical conditions which had affected a significant ecological factor - the conditions of gas exchange of the suspension with the air. The results show the possibility of a practical importance of such studies for BLSS, while the very cultivation technique of various organisms may become an independent object of the weightlessness effects.

The ambiguous role of the weightlessness influence was observed also when studying the embryo development of birds (the Japanese quail). In 1979 a joint Soviet - Czechoslovak 
experiment with the eggs incubation was run on the biosputnik "Kosmos-1129". According to the flight conditions, the incubation process in flight lasted 11.5 days instead of 18 necessary for the complete embryogenesis. The principal result of that experiment was the direct proof of the possibility of a normal embryonic development for part of the birds, at least at the first decisive stages embracing $70 \%$ of the embryogenesis duration. There was a considerable number of undeveloped embryos (35\%), and besides that, a great frequency of morphological impairments of development, though it had obvious reasons: a long storage of the eggs before the beginning of incubation, a high temperature during the last 10 days of storage $\left(23-28{ }^{\circ} \mathrm{C}\right.$ and a decrease of the air humidity to $30 \%$ during the second half of incubation (Shepelev et al. 1982).

The complete cycle of quail egg incubation was performed in 1990, on board the orbital station, in the course of Soviet-Czechoslovak experiment with the use of the second generation of the incubator, also produced in the CSFR. It was the first time that under the conditions of weightlessness eight normally developed viable chicks were hatched with normal motor, feeding and vocal behaviour; this is the final proof of the possibility of normal embryo development of birds under the weightlessness conditions ( $\mathrm{G}$ u r y e v a et al. 1993; Meleshko et al. 1991; Sy tchov 1983). This experiment also revealed a considerably smaller (as compared with the control) hatching rate of the chicks and a higher frequency of abnormal embryo development at different stages, although unlike the previous experiments, there were no unfavourable conditions of egg storing before incubation and no interruptions of the incubation regime.

Some cases were observed of an abnormal longitudinal situation of the embryo and of the developed chick, with the head in the narrow end of the egg, which hinders the process of hatching of the chicks.

When considering the results of the experiments on the eggs incubation in weightlessness, we probably deal with qualitatively different categories of dependences. As for the mechanism of the formation processes in the course of the embryo development, it must be determined strictly enough at all its decisive stages and is not exposed to the weightlessness influence in itself. This is shown also on the example of mammals (S e rova et al. 1988). Weightlessness can alter the conditions of embryogenesis within the egg itself. This seems quite probable, taking into consideration the unequivocal gravitational dependence of the egg's macrostructure, the components of which (the yolk, the albumen, the air chamber and the embryo itself) in the terrestrial conditions are located along the gravity vector at a definite location of the embryo in relation to these components, especially to the air chamber. Under the conditions of weightlessness, the egg's macrostructure may be either kept or broken, which may worsen the conditions of respiration and the embryo's metabolism itself. A halt of development is possible at different stages and various types of its impairments as a manifestation of an indirect influence of weightlessness observed in our studies of the embryological material.

The first viable chicks hatched in weightlessness and the first 2 to 4 days of their life under these conditions had suddenly put forward a new problem of an essential significance for BLSS. It was the fact that at that time the chicks possessing the visual orientation could not acquire skills of the fixing the position of the body in the space. They only "floated" in the volume of their chamber being in the state of a random rotation, worsened by abrupt movements of wings and legs, in spite of the directing air stream towards the netlike floor that allowed to seize at it with the claws (She pele $v$ et al. 1993).

The videotape analysis has shown that acquiring motor skills adequate to weightlessness is hindered by the antigravitational innate reflex of pushing from a support when touching it, which is natural and useful for a neonate in the gravitational conditions. It is quite obvious 
that this opens an entirely new problem of forming the motor behaviour of a neonate in an agravitational environment which is adverse to the existing innate mechanisms. This problem solved by means of learning and training for humans may become limiting in the course of using BLSS in the conditions of weightlessness and concerns certainly not only birds but any free moving (not fastened to the substratum) organisms.

After that the adult birds were observed. In 1990, 3 female and 1 male quail at the age of 60-65 days were delivered on board the station "Mir". They spent in flight 8 days, including the day of flight on board the transportation vehicle. Then they were placed in a chamber (where the chicks had previously been) in individual fixing "jackets" of a hammock type near the feeding throughs. The specially prepared paste-like food contained the necessary amount of water so that there was no need for a special device providing the birds with water (A b a k m ova et al. 1990). The active food intake began in the very first minutes after placing the craft into orbit.

Before the flight the females were in the phase of active egg-laying. In flight they stopped the laying at once. The last egg was laid by one of them during the delivery into orbit in the transportation vehicle, and a normally developed chick hatched from it on Earth. This corresponded to the morphologically marked hypotrophy of ovaries and oviducts found immediately after the flight in one of the females. These impairments that were inherent also to the birds of the synchronous control are well accounted for by the non-specific stress reaction to the mechanical conditions of the flight and appeared to be reversible. By the 7th-8th day after landing, and at the same time in the synchronous control, the laying activity was restored, and the very first eggs received after the flight gave a viable progeny which has counted many generations by now (B o d a et al. 1992).

Of great interest was the motor behaviour of the birds under the conditions of weightlessness. While on orbit, one of the birds was twice released from the fixing "jacket" and let out into the working module of the station. The videofilm has shown that during the first seconds after being released from the hands the bird had hung motionless in the space in a "collected" position, but after the very first movement a chaotic rotation occurred. Unlike the newly hatched chicks, however, it could make short straight flight suntil it touched the wall of the module to which it had no possibility to cling. In one of such flights the bird had returned to its chamber and immediately began to peck the food. Of course, these observations are not sufficient to judge about the possibility and the process of the birds' motor behaviour adaptation to the conditions of weightlessness; but even at this stage it is possible to perceive the essential difference in the capability of adaptation of the adult birds as compared to the newly-hatched chicks. The adult birds already possess an initial adaptation basis in the form of individual habits of motor behaviour well established, if only in the gravitational environment, and here we can speak about the adaptation of already existing habits to new conditions, especially taking into consideration that for moving with the help of wings the aerial environment on board a spacecraft is as adequate as on Earth.

As for the newly-hatched chick, it has not yet any individual habits of behaviour outside the egg, it has no initial basis which could be adapted to anything and its innate basis (unconditioned reflexes and instincts) are certainly inadequate to the conditions it has been hatched in. Perhaps it is more correct to speak not of adaptation but of a completely new psychological and physiological problem - the primary formation of behaviour habits in an initially inadequate environment at an initially unsuitable and even harmful basis of unconditioned innate mechanisms. It is doubtful whether this problem is solvable at the first period of post embryonic development. The only obvious fact is that this problem concerns not only birds, it has a general biological significance and will become limiting for some variants of the heterotroph link of the BLSS. It will not exist only for animals which do not 
lose the connection with the substratum (molluscs, for instance), or for climbing animals which possess an innate seizing reflex.

While estimating the issue of BLSS in a long-duration space flight the following conclusion of a prognostic character can be made: in the course of transition theoretical calculations and ground-based modelling of closed ecological systems to their practical implementation on board the spacecrafts, the significance of the weightlessness factor will more and more influence the choice of biological objects, the technique of their cultivation, the definition of the biocenotic structure and trophic chains in the designed BLSS. But it is already obvious enough that this limiting role of the weightlessness factor will manifest itself not through the primary changes of elementary vital processes in the organisms, but through a number of mechanisms of indirect influence on all the levels of biological organization, which finally shatters the evolutionarily formed unity of organisms and environment - the indispensable conditions of life on Earth in all its manifestations.

All this requires a new, ecological stage in the development of gravitational biology which is already close to exhausting its initial task. A vast and convincing material has been gathered in favour of gravitational independence of elementary life processes; the further task is investigation of super-organism levels of life, for only on these levels it is possible to find the real general biological (ecological) significance of gravity for the terrestrial forms of life and of the consequences of its absence in the conditions of a space flight. This new subject of research requires new approaches, methods and means.

\section{Stav beztiaže ako podmienka realizácie BLSS}

Realizácia BLSS (Biological Life Support System - Biologický systém zabezpečenia života Iudí) v podmienkach stavu beztiaže vyžaduje širši ekologický prístup k analýzam manifestácie stavu beztiaže $v$ biologických systémoch $v$ porovnaní s tradiěnými morfo-fyziologickými prístupmi, ktoré sú bežné pre gravitačnú biológiu. Pre stabilné fungovanie BLSS ako ekologického systému sú rozhodujúce úrovne jednotlivých článkov biologickej organizácie od populácie po ekosystém. Na týchto úrovniach sa môžu ukázat prejavy stavu beztiaže dokonca aj v prípade, keđ nie sú pozorované žiadne základné biologické efekty na úrovni organizmov.

V práci sa diskutuje o možných spôsoboch prejavov stavu beztiaže ako aj ich dôsledkov. $\mathrm{Na}$ rôznych úrovniach organizácie biologického systému od bunky až po ekosystém môže mat stav beztiaže rôzne mechanizmy vplyvu a jeho účinky môžu byṫ realizované rozdielnymi spôsobmi.

\section{Невесомость как условие реализации БСЖО (биологической системы жизнеобеспечения)}

Реализация БСЖО человека в условиях невесомости требует более широкого (общебиологического/экологического) подхода к анализу проявлений невесомости в живых системах по сравнению с традиционным морфофизиологическим, в сложившейся гравитационной биологии. Для устойчивого функционирования БСЖО как экологических систем решающими являются надорганизменные уровни биологической организации от популяции до экосистемы. Применительно к этим уровням влияние невесомости может проявляться и при отсутствии каких-либо первичных биологических эффектов на уровне организма.

В работе обсуждаются возможные пути воздействия невесомости на биологические системы и точки приложения этого воздействия. На разных уровнях организации живых систем от клетки до экосистемы невесомость может влиять разными путями, иметь разные точки приложения, а её эффекты могут реализоваться разными механизмами. 


\section{References}

ABAKUMOVA, I. A., GURYEVA, T. S. , TRESVIATSKAYA, N. A. et al. 1990: Kosmicheskaya biologia i aviakosmicheskaya medicina. Tezisy dokladov. Kaluga, pp. 396-397

BODA, K., SABO, V., JURÁNI, M., GURYEVA, T. S., KOČIŠOVÃ, J., KOŠTÁL, L., LAUKOVA, A., DADASHEVA, O. A. 1992: Acta vet. Brno, 61:99-107

GURYEVA, T. S., DADASHEVA, O. A., MELESHKO, G. I., SHEPELEV, Ye. Ya., BOĎ, K., SABO, V. 1993:Aviaskosmitcheskaya i ekologicheskaya medicina, 27:71-73

KORDIUM, V. A., POLIVODA, L. V., MASHINSKI, A.L. 1976:Problemy kosmicheskoy biologii. 33:230-260

MELESHKO, G. I., SETLIK, I., KORDIUM, V. A., DOUHA, J., GALKINA, T. B., POLIVODA, L. V. 1979: XII symposium po kosmicheskoy biologii i medicine „Interkosmos“, Krakow-Warszawa, Tezisy dokladov

p. 31

MELESHKO, G. I., SHEPELEV, Ye. Ya. , GURYEVA, T. S., BODA, K., SABO, V. 1991: Kosmicheskaya biologia i aviakosmicheskaya medicina. XII:37-39

MELESHKO, G. I., SHEPELEV, Ye. Ya., KORDIUM, V. A., SETLIK, I., DOUHA, J. 1986: In:Resultaty medicinskich issledovanij, vypolnennych na orbitalnom nauchno-issledovatelskom komplekse „Saljut-6Sojuz", Moskva, Nauka, pp. 360-380

MELESHKO, G. I., ANTIPOV, V. V., GOLOV, V. K., LEVINSKICH, M. A., PALMBACH, L. R., SYTCHOV, V. N., SHEPELEV, YE. Ya. 1992: In: Resultaty issledovaniy na biosputnikach. Moskva, Nauka, pp. 378-383

PARFYONOV, G. P. 1988: Problemy kosmicheskoy biologii. Moskva, Nauka, v. 57, P.268

POLIVODA, L. V., 1988:Chlorella kak modelnyj objekt dla biologicheskych issledovanij. Autoref. diss. kand. biol. nauk, Kiev, 22 p.

SEROVA, L. V., DENISOVA, L. A., LAVROVA, Ye. A. et al. 1988: Ontogenes mlekopytayushich v nevesomosti. Moskva, Nauka, pp. $72-79$

SHEPELEV, Ye. Ya., MISHENKO, V. F., BODA, K., FOFANOV, V. I., DADASHEVA, O. A. 1982: XV Soveshchanije rabotchich grupp sotsialisticheskich stran po kosmicheskoy biologii i medicine, Interkosmos, Bucharest, pp. 121-122

SHEPELEV, Ye. Ya., GURYEVA, T. S., MELESHKO, G. I. 1993: Acta vet. Bmo, 62:61-63

SYTCHOV, V. N. 1983: Rost i razvitie odnokletochnych vodoroslej v nevesomosti, Autoref. diss. kand. biol. nauk, Moskva, 22 p. 